\title{
論蘇聯科轟院1952年科軖研究 工作的計劃
}

\section{一一蘇聯科學院學術秘書長 A. B. 托布契也夫院士在 1951年}

\section{9 月 14 月蘇聯科學院主席團會議中的報告}

\section{4}

$\alpha$

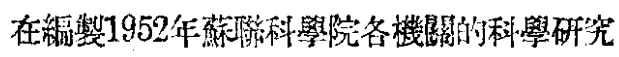
計制恃, 各部、各分院以及各研究所是受着正在望

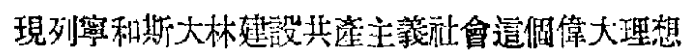
的湳國呧當前任務所引導的。

戰後斯大林五年部劃的順利實現，一旦国民

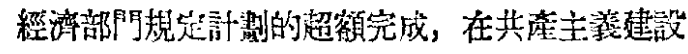
中,蘇維埃國家整润多方面活動的巨大規模，這一 牙說明我們是按照偉大斯大林所指示的道路腾利 地向前苟僬。

我國人民的物質和文化水平不斷地提高，蘇

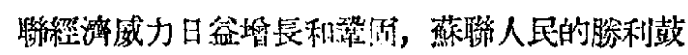

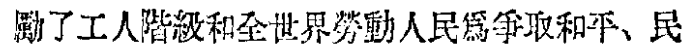

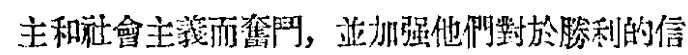

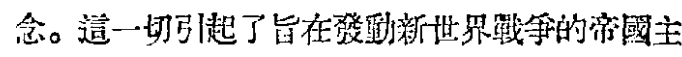
湶國家中統治集團的瘋狂的㤯怨與仇恨，美國强

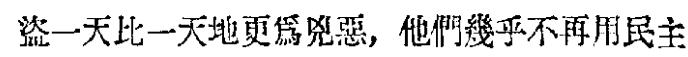
的外表㭺旍着了，一天比一天地、更完整地、更篇 道率地罚路了他們的野篮法西斯的面貌，帝國主

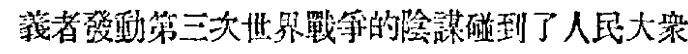

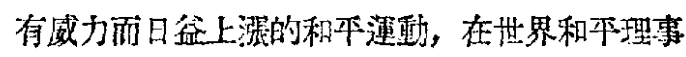
會路召之下所徵箱的百萬億人的签名裁示了世界 勞動人民筑拿取和平而班笔的堅定不拔的意志。

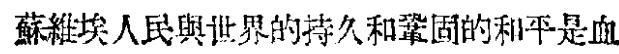

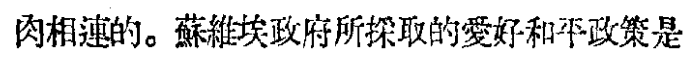

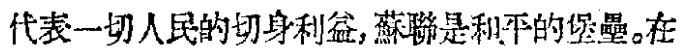
世界和体理事會關於綿結五大闻和平公約的號召 之下，我國展開了签名運動，這是保䘖和平事業有 堅强决心的葆維枝人印的意志的有力的表現。

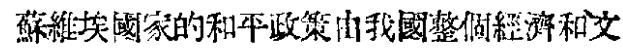

化發展的道路所决定。自從蘇維埃政府公佈了關

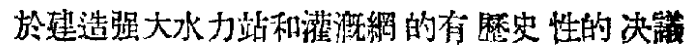
後，已經過了一年,這一年說明了創造共產主義鳘 源基礎的偉大斯大林計劃是正在成功地望賁現着，

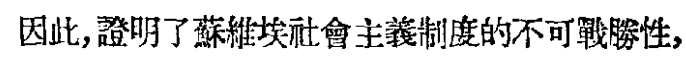
登明了它比皎資本主㼁制度是有無限優越性的。

過去這一年也登明：繖維埃先淮科學與國民

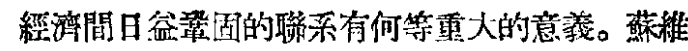
埃學者因篇有克分的志願䍃共產主義建設事業貢 㱆所有的能力和知識，所以集中力量以解决我闻 國民經橓中的實際問题。將科學的成就應用到生 崖中, 這是今天蘇聯科學院所應當賽現的主要任 務之一。

我國共產主義的建設對於科學提出日谽更新 的問題。這些問題只能在最先進的科學理諭基礎 才可以解决。經党發罢着和䁷䈏着的馬克思列察 主蓖就是這種理訜。

斯大林在他的琵施語學學問題的天才著作 中，筧總結過去歴史上的經驗、給馬克思主義下了

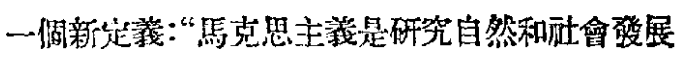

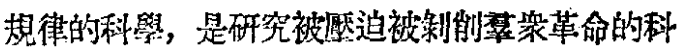
學, 是硼究社會主義在一切践家中勝利的科學, 是 研究共座主義建設的科學”。

這倜定義把馬克思列蜜主俄推潢到一切知識 部門, 是澈底地售示了馬克思列鼻主義無所不包 無所不容的特性，當我們執行科學研究工作時，我

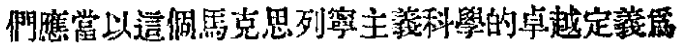
出發繁, 盡我們所有精神、所有能力赫行斯大林所 提出的創造共座主妾經滴基礎的任杵。

第卡期科學通報 


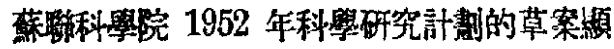
㵔地比上一年的計劃好。它反胦着國民經濟的要

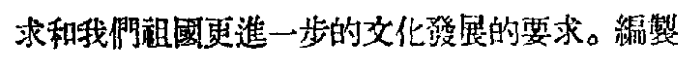

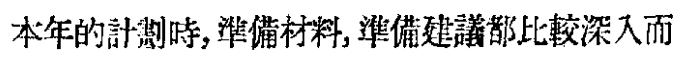
有目的。各科學楼䧼、各部門以及科學院的各會 議一年來已經加强了眮政府各部各行政機關的聯 系，所以目前比較更能了解國底經湾的要求。因 此, 所提出來的題目更篇全部地反胦我國經滓和 文化建設中的䁈際任務。1952 年的計剩中包括 149 项重要問題，遥些問题的解决可以正接垶助 筫現共產主義的缭大建設計雃。

我們可以有信心地說, 1052年部割草案中已 敉浔有過去那些很難根除的“黑痣”了，在汁劃中 沼有只文胦科學工作者倨人的部分的興趣，而不 注意整倜國家的任務的問題了。

計割中有一唀特點, 就是許多題目踓然是過 渡到1953 年才能完成的, 但是在 1952 年的階段 就将完成浆一完整部份的研究, 這一部份研究的 結果可能期時得到㮣用。

比較 1951 年已經加增了科學研究的称合性， 1951年綜合的問題有120項,1952年增加第165項。

淮借 1952 年計劃時, 比較完饪地改虙到蘇 聯科學院的各分院、各加盟共和國科學院以及各 専門科學機關間，計劃的配合。在這方面，“偉大斯

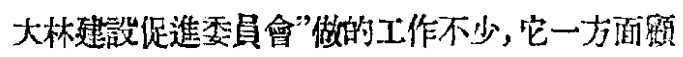

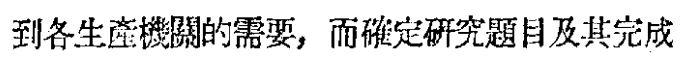
的期限，一力百面使科學院的各部、各分院和各加盟 共和國科學院間得到適當的分工。

關於各项問题的棕合解决和相 厉配合的工.

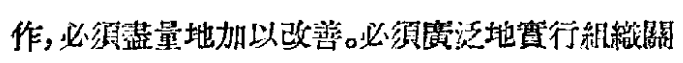
於科學研究的棕合和配合的委員會。

在新計劃中減少了題日的繁雜性, 踓然在這

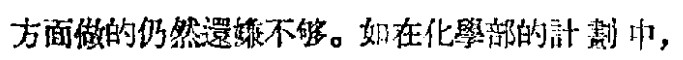
1951 年有 343 项, 1952 年草案則有 280 项, 挍術 科學部 1951 年有 140 項, 1952 年则篇 120 项, 經 湾學與法律學部 1951 年有 164 項，1952 年则篇 103項。

各分院的計犃根体改變了，以前在分院中有 一璉不好的替慣，在邆給政麻批准的計乵以外，還 有所請“分院內部的”計劃。這類計劃的䋧丵與完 成是不受检查的, 1952 年分院的計劃是㓍一了。

學替斯大林關於語言學的天才著作在理諭上
武裝了我們的學者，使他們能確定各科學部門中 研究工作的方向, 能計劃科學院更進一步的科學 業務。

現在我要說到各部門和科學院各會議的計棒 的简略情况:

\section{一 物理一数悬部}

1951 年本部各所篔完成了大量的工作，獾得 許多新的物質資料 (墢光物質牛道體, 絕䍃物質, 棕合晶腊)，擬定亚開創了新的方法來研究和检查 許多各别技術程序。

關於對國民經济各部門有重要意義的故射物 理學, 聲學尤其是水警學方面的工作, 得到了䫏著 的發展。

在斯鐵克洛夫数學研究所中, 進行着對於數 學中現代的一切基本部分的工作，以及在工業及， 其他科學部門，如物理學和技街科學中，獲得直接 應用的工作，特别成功的是院士維諾格拉多夫所 領渻的分析解論研究工作。

根㨜斯火林在其天才的語言學著作中的指 示, 本部舉行了關於天體演化學的討論會。

但是，除了成就以外，同時须要指出的，本部 1951 年科學研究工作計劃所列的 273 倜題目中 就有六程份有米完部分(地球物理學研究所一種, 海洋物理學研究所五種)，四種汥有完成(結晶學 研究所一種,地球物理學研究所二種, 海洋物理學 研究所一租)。

1952 年本部的科學研究工作計劃的特點在 於物理學和地球物理學的大部分題目是與國民經

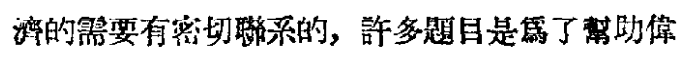
大共座主義貄設而擬定的。

在數學上，直接適用於工業上和適用於其他 蕅带有關的科學部門中一一物理學和技街科學一的題目，㙷著地增加了數目。

在將要到來的一年中，天文學家椚的面前展

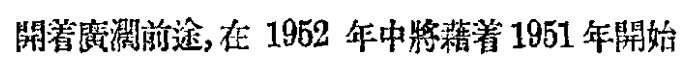
動用的巨大天文義器之助而展開工作。例如, 在普 爾科大湕筑的大天文台完成以後, 特有許多重要 的天文學檥器開始滤用:天顶儀, 6 公尺的星光干

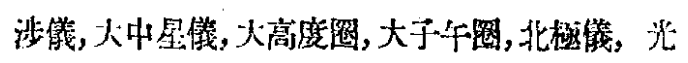
留經緯嘎。在克里米亞天體物理舉的天文台中，已 經開始動用的有殹洲最大的 125 厘米的反光等遠 
鏡, 星球電光照像儀及其他。

經過盧泛的討論，對於天體演化學的研究定 出來綜合研究的程字, 執行這種工作㭙镍聯科學 院的許多部門以及各加盟共和或科學院和各院外 機關將來也要參加的。

1952 年本部科學工作計哄中有 42 佪閣題， 其中 7 倜是綜合的, 共包括 280 倜題目。

在物理學範溒中䌜要發展的工作有分子物理

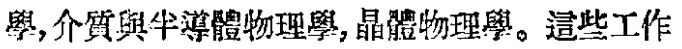
可以保璒獲得我椚工業上必需的具有一定特性的

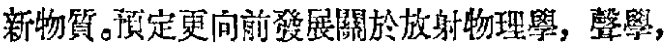
特別是關於水馨學和低温物理學的工作。

地球物理學研究所將要繼續進行以下的工

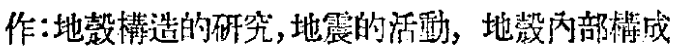
和發展, 大氣凅的物理過程的研究。

在地球物理學研究所的工作中，對於改善垷

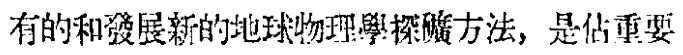
位地的。

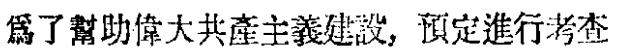
土庫曼大運河綛過的路程, 以求根據這種考查建 檨在建策速河的工程中㗹當探取防借地震的措 施。

在海洋物理學研究所方面, 在完成E大的陚 驗風暴的水池的建築後, 特開始研究風派的發生、 發展和平息。此外，研究所将要研究大陸、大氣和

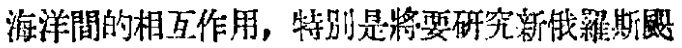
風的機棈。

數學研究所計劃發展現代數學中所有主要部 分, 此外特別注意的是研究数學物理中的微分方

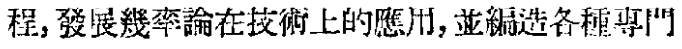
性的表。

在 1952 年物理一数察部的工作計劃中,首先

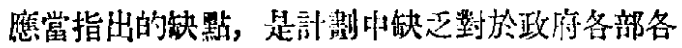
行政機關雔有的配合性, 這程配合性在關於計劃 的進一步工作的過程中是磼畄蒸到的。

計劃中另一储缺點是題目繁多，如海洋物理 學研究所中的人員蜼然有限, 研究題目却有 13 種 之多並包括 28 倜分題。

地球物理研究所的工作題目比 1951 年. 多一 倍,並且獨立研究的題目中有“ $\Gamma E$ 式電湤器之研 究以求改善其整造並更提高其敏感度”, 這倜題目 顼定要研究整倜一年的時間。

第六期
本部在自己的工作中與蘇聯科孟院各分院以 及各加盟共和國科學院間的聯系省少。

\section{二 化䍘部}

在 1951 年中本部各研究所在密切與菣維埃 化學的發屡相聯系方面，在密切地與化學的、石油 提䅘的、冶金的以及其他的工業部門相聯系方面， 筸完成了大量的工作。

各研究所根提斯大林在其關於語言學的天才

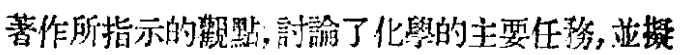
定了以批棓的態度處理化學中各项問连的辦法。

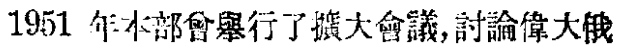
羅斯化學家作特列眓夫所創始的化學結棈 學說。

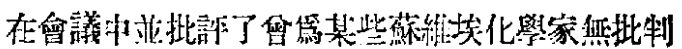

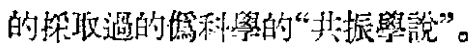

1951年上代年枯部各㸴觉所的工作中已經有 了成就，洌如，何機化學研究所成功地研究新型的 人选瀻維及其整造原料，研究應用於水利上的新 程類液體，砄究留族化合物 [甾曋災]，庫雨納克夫 晋通化學與组機化學研究所成功地完成着雨種對

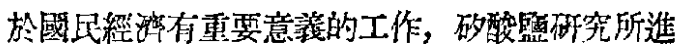
行研究且閒玻瑞、玻璃磨光程序的合理改進。高分 子化合物研究所獲得了一程高度抗繁有機玻瑞。 其他破究所也有成就。

蜼然如此，但是份份些工作不能按期完成的。

1952 年在化學研究论前份棈最重要的任務,

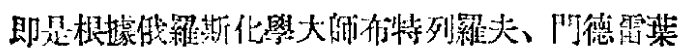
夫、瑓雨納克夫、謝林斯基等人的學說，更進一步 地研究现代化學理猃問题, 研究证掌握對於改造 自然原料和工業原料的行效方法, 研究品化和合

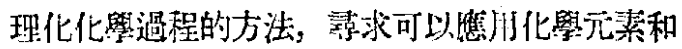
化合物的新陾域，找出称究和支配化學過程的新

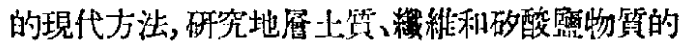
新程類、新的抗強整合金等等。

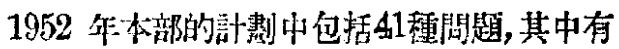
8 種是綜合性的，綜合性的工作是與間过經濟中 重大問題有關係的(如研究催化刲學馀, 稀有和分 散各地少量的金虚的化學工作，新的金屬合金的 問題)。對於綜合性的問題不只化學部的各研究所 參和, 其他部聞的研究所也要害加。

配合關於化學構造學說討諭的結果，1952年 的工作計劃擴大了對於化學構造學說和化合物反 


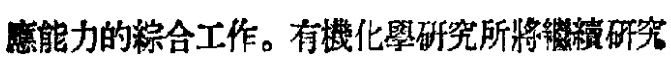
原子的相西影響及其結合關是，元素有機化合物 的特性, 鹠烯合成反應的方法等。

以現代物理的和物理化學的方法㣹用於研究 化學過程上，得到更進一步的發展。如同在高分子 化合物研究所中，以紅外線光譜、聯合色散光諳、 電子顛微鏡、偏振作用、譍折射及其他方法將應用 於研究荟分子的性筫上。

化學物理學研究所,物理化學研究所, 維酮納 德斯基地質化學與分析化學研究所及其他研究所 在研究化學過程和化學物賀的構造時廣泛地熄用 噖定性同位素和放射性指示謌。

在計劃中有許多有關水電站、運河、蓄水湖建 笔的新任務。加强了水系化學的工作，保護地下金 屬建築和水泥裝備的研究，擴大了對於新的金罣 建筑材料的物理化學的研究。

1952年計劃中有許多新面目是有很大科學的 和圆民經济的意㼁的,例如，有機化學研究所提出 下列的研究工作:

含硫石油的極度的改良；

研究用作高效離子代謝樹脂的原料的倠化合 成作用;

研究對於高効率添加然料的方法；

研究類似天然産物颛有生理性能的人造甾族 化合物;

研究水湛機維的合成;

研究乙烯化合物的聚合作成。

普通化學與㷛機化學研究所将要找出提煉和 分析貴重金蒝的更完善的方法，研究許多稀有元 素的性战及其分離、分解、分析的方法，在高熱度

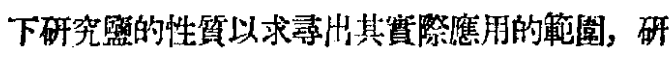

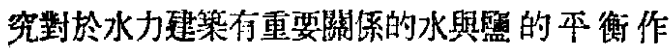
用,科學地建立有賽用上重要性合金的製造法，研 究金屬的固體混合物與化合物形成的規律性。

維西納德斯基地質化學與分析化學研究所將 要改善鑑定地款石居年龄的方法，研究鉛與鈤的 生物、地資化學和鉬與䲧的地質化學。特製出有 采䩙的世界煤啳圖，特別注意的是合石油的盆地 䂡床的地質化學問題, 以求境明地殻石居的組成 及其含石油量的閣係。

在物理化學研究所中，以下的工作将要得到 秷展：

- 374 •
研究關於防止海上建策受侵领的方法;

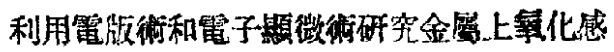
光膜的保護性質;

研究製造色首分離法的自動器;

研究在離了一代謝樹脂叫離了的分離;

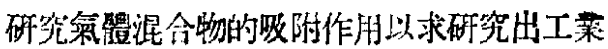
上分離它們的方法；

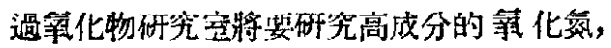
奥化物，证研究出元素過氧化的合成方法；

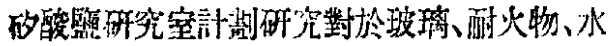
泥生產有重要意義的新方式, 在此工作中將要應

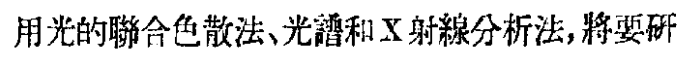
究電介質的和歷電的性質, 蓝研究知道份少的矿 “ 酸孟類化合物的彈性與汀塑性。

1952 年本部的科學工作計劃少有些不够的 地方。在計劃中佮許多過渡的題目, 1952 年可以 結束的題目霞數份少。必須指明的, 1952 年工作 中二大部分題目的工作絬果只限於富報告和篇定 期刊物竄文意，很少的部分可以供給㐿關機關或 国民經濟通接㷪用的。

在計暗中佔的地位不够的還有：研究光合作 用的工作，研究稀有元素㷳肋於工業上的何能性

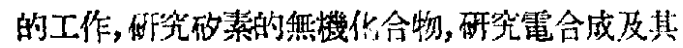
他有高度能量的化學過程。化學部的計亚與科學 院各分院的化學研究部分聯系不够。

1952 年本部將開始出版布特列翟夫文選，光 成門德雷集头至集的初版, 進行出版院士謝林斯 基、院士波笨・可什荻、院士赫洛本、院士維爾纳 德斯基的選集，以及其他化學部分的選集。

\section{三 地買一地理祭部}

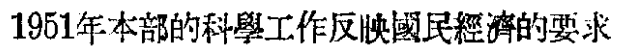

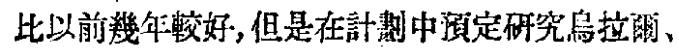
土瓦澡和遠莫區物質剘富的工作仍然不够。對於 一般碃累的賽際材料的研究工作, 對於研究地質 地理科學中理論基磼的工作，注意也不够。本部各 閶間，以及它們與蘇聯科學院各分院間, 所進行

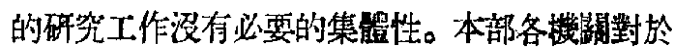
各分院的科學領導不能。

本部及其各機關探取行動成功地，踓然還是 不够,執行了 1951 年的工作計剖。大量的精神集 中於完成 1950 年所搜集的材料的研究，對於發 


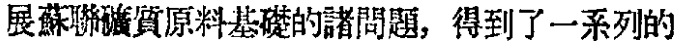

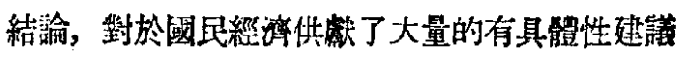
的專諭、結論和報告。在偉大共应主義越設的區 域中, 筧進行了關於地質地理條件的大量研究工 作。

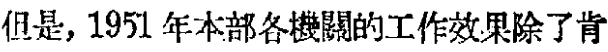
定的方面, 還保在着不足的地方。

例如，地質學研究所(所長瓦林曹夫敎授) 直

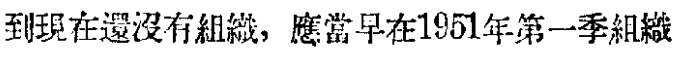

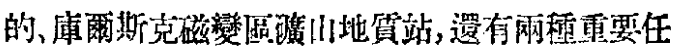
務也遲延完成。

地理學研究所在執行計劃工作中也汥有做 好。

薩瓦林斯基匆力地質開題研究空執行工作計 劃也是照鹤地不好，1951 年15項計劃中就有 9 項 發現有不能完成的绝險, 而其中大部分是與偉大

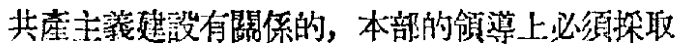
紫急措施以保登1951年計劃的實現。

1952年本部工作計割草案中規定了5種棕合 研究的問題和33種非綜合性的問題, 包括 257 倜 题目。

草案中規定的研究工作將要帮助地賢、地理

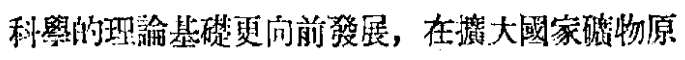
料基地上和賽現改造自然的斯大林計㖆上解决一 些具䭪的問題。

1952 年本部工作計劃的草案與 1951 年計㳯 比較有許多特點: 在研究我國辚方、東北方和北方 咞域的工作上是撗大了梁入了。關於偉大斯大

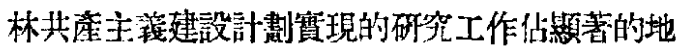
位。

在計劃草案中教滤到政府各部和行政機關的 意見與要求, 計劃的一大部分, 踓然是還不够宎分 程度, 是颃先得到有關機關同意的。

1952 年地質研究所的基本活動是在我國各 區域研究並尋找未開採的砤物新产地。也規定出 帮助偉大共產主義建設的工作。

在地理研究所的計劃中，佔重要地位的是研 究偉大建没計劃區域中的自然和經浖, 這類工作

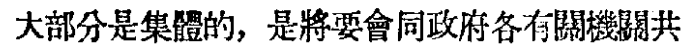
同進行的，同時對研究各人民民主國家地理的工 作，也預定予以極大的注意。

海洋學研究所將進行的工作是研究櫋界海
洋, 裏海水位的變化, 蓄水湖的生物生座力，以及 薢聯海岸的紀錄。

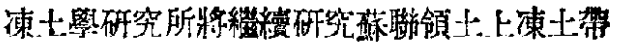
分作與發展的規律性，研究水碀地款石詹和水的 物理學與力學。

1952 年的計劃草案比較 1951 年踓然有顆明 的優點, 但是其中還有噘重的缺陷。必須指出, 草 案中缺點之一是研究題目比 1951 年加燳數目 (1952 年 257 偑, 1951 年 239 偑)。不能容忍的, 是存 8 個题目，随意延長結束時限。有許多闍題不 够明晰，特别是關於岩石學。並且問题的提法只是

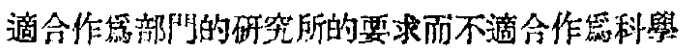
院研究所的要求。

在進行科學研究工作中集䐺性的發展不强, 例如，在研究蕉聯源洋方面的大量算際材料的整 理, 必須墢動本部的其他研究所。地理研究所和地 質研究所在研究些產主㼁偉大建設區域中地質形

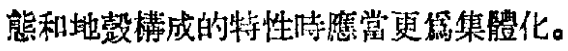

\section{四 生物科淟部}

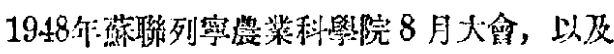
揭路以院士奥爾别里與院士别里塔施維里篇首的 生物學中反巴甫洛大的學派，根據勒柏辛斯卡嫖 卓越的著作提露微耳和學訜的反勒筫質; 以斯大 林在其天才的語言學著作中所指示的觀點，同科 學中的教佟主義和學究主義進行网学，這一些蘇 聯科學中歴史性的大事確定了生物科學部門各機 關的科學研究方向。

實現偉大共產主義建钤和斯大林改造自然的 計劃在本部工作中有了庴泛的反肤。

但是, 踓然有極重要的肯定性的改進, 本部各 機關工作中也還是有缺點。1951 年-本部門的否定 方面是它的題目太繁多，有許多題目的挩定與國 民經濟的要求聯系得不够。检查 1951 年上伴年本 部門工作的結果，登明個別研究所有不完成計劃 的情事, 動物形態學研究所 (所長賀魯曹夫教授) 也在其內。在生物學研究所 (所長貝柯夫院士)及 其他本部的研究所中也有許多未完成的題目。

在生物科學面前有一些重大柴要的任務，必 須更深刻地研究生物學中最重要的理諭問題。一 部各機關及全體科學工作人員應當特別注意竩圆 生物科學諸大䢹的科學透㡾，特别是季米里亞席 
夫、米邱林、巴甫洛夫及他人的理論的創造性的發 展。對於斯大林改造我國自然計劃中主要理論問 題和科學宾践問題的研究, 對於水力中心區的建 信計劃和水利灌溉地區的經濟情况掌握的研究， 㮣澢供缺主要的創造性力量。

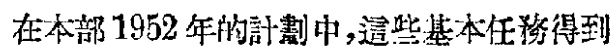

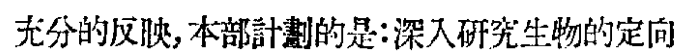
變異和品種改造，生活力與遗傳性; 研究代謝作用, 氮基酸代謝過程，球蛋白的增長與溞隇，研究程他 命, 發酵過程的規律性, 非細胞形式的生命, 生化 合成作用問面。特别注意的是研究光合現鱼。

预備根㨜新陳代謝作用的支配, 研究如何提 党有機显的生殖力。

計劃中炶顯著地位是: 研究微生物發屡的規 律性，它們的遺傅性，及微生物性筫的定向變異; 研究病瑇性頃及非和胞形式的生命。

對於巴甫洛夫生理學，特别是高級神經活動 問題, 淮供廣泛地研究, 將要研究高級神經活動的 资本規律, 神經系統類型的生理學, 研究第二信號 系統與第一信躆系統的相五作用，研究有機體外 部與內部環境分析器的生理嚳。

各研究所面臤的重要任務是以隐床筫驗研究

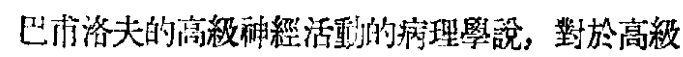

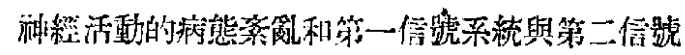

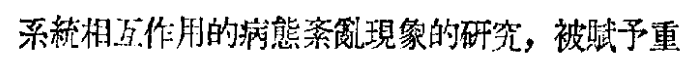

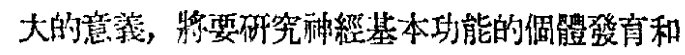
系統弡交。

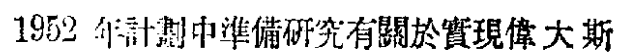

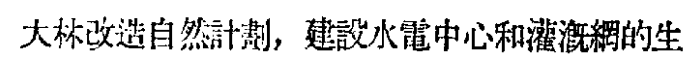

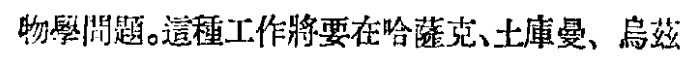

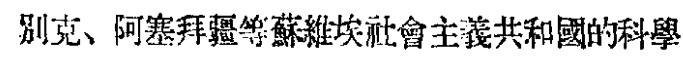
院以及其他科學研究機關共同势力下進行的。

在弡展斯入林改造自然計劃方面, 計劃的工 作是研究伏爾加河左岸，裹海沿岸低地，中亞細 亞, 及防渢标種植區的地方植物區系, 動物區系, 地首上塯, 及森林稙物生活保件。

計劃研究的問题: 獲得高度而稳定的收檴量,

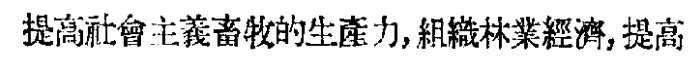
蓄水湖的生物生庆量。關於這些問題的野外工作 將要直接在那些需要根本改造的地區, 聯系着各

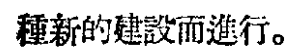

計割中的, 還有改丵食品工業的整造技術原
理的工作。

因此,在生物學部的計劃中，蛙各璉理論問題

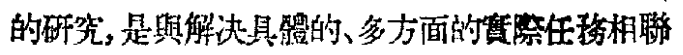
系的。

計割中䫏著的特徵是其集體性，各生物學研 究所中所有多樣形式的小题目統統路納到 13 種 基本方向，很多工作是會同政府有關各部和各行 政機毁的科學和生產機構共同進行的。21储題目 是根㨜政府各部及國家計㓡局的赽議列入的，例

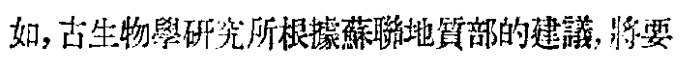

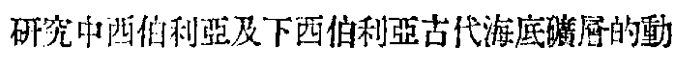

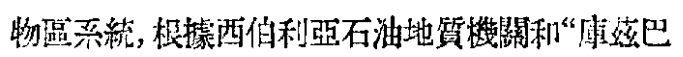
斯煤屡地質”組合的要求而䂰究許多其他題目。

在準備工作計劃洔，本部是會同食品工策部， 林業涇游部，國營農場部，魚類工業部等代表洏决 定科學的主要題目。

不讋地，計劃中仍存在着缺點，同以前一樣， 也是題目太多。1952 年本部計劃的奎部題目有 598項。

\section{五技術科學部}

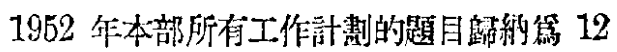
倜大問題。但是在許多情形中這些趼納只是形式 的，原因是本部各機關的合作還是不够，必須確 認，有很多题目的完成落後於期限。1951 年計劃

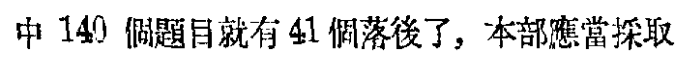
嚴重的措施使本年國家科學研究計劃得以完成。

在前位年中有許多研究所進行了有意義的工

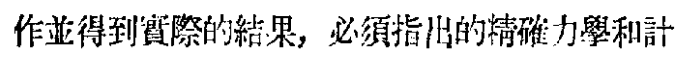

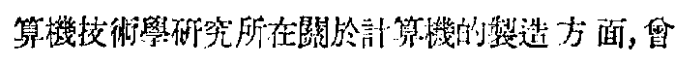
進行了大量的工作。

但是，菆術科學部中准些科學機關在工作上

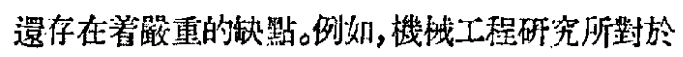
幾種重要機器的建造學理, 關於機器製造中新材 料的探用, 關於建立連續生產的自動裝借與自動

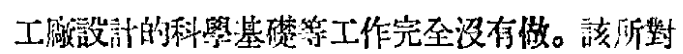
於機器製造的幾種技街學問题也沒有進行, 對於

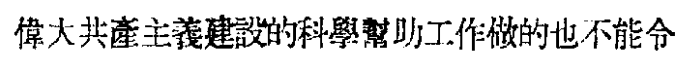
人㴖意。

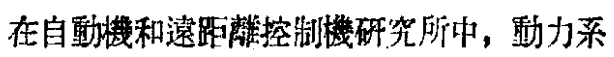
統、電訊、蓮輸的自動化的工作沼有做，對於古比 雪夫和斯大林格勒的動力和水力聯合工㡟的遠距 
離控制㙨器化的工作發展的完全不能合人滿意, 道使得1951年此一題目的工作計劃大偖終止執行 的危險。

磷冶研究所㮛據1951年的計劃發展了些小的 题日，以致分散了力量與資金，並制弱了工業研究 所的珹縝。

力學研究所直到現在倫未完成䒺聯科學院主 席團對於筂展航空動力學和氣體力學工作的决 議, 很少注意於工作的應用方面, 而且有些工作多 䐂抽像性筫。

在動力研究所中, 關於巨型電機的工作浑有

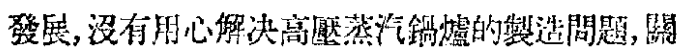
於蒸汽渦軨機和氣佩输機的工作也汥有做。對於 設計新的更現代化的高温蒸汽發電站的團案，該 所完圣沼有下手,還有兩種工作,該所在数月時間 中浔有把工作發展到睢有的高度，以致使1951年 的工作計劃有不能執行的危险。

本部各機構的游動中珗有了這些缺點自然影 響到1952年的計割，因此在計割中找不出活多第 我國國民經濟所提出來重要問題的反胖，而對於 許多問題的研究也是計劃得不够光分。

1952年本部計㓶中所提H的問題, 基本上是

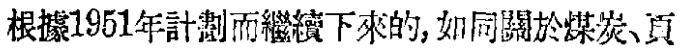
岩、泥炭、石油、生鐵、銓、與有他金屬諸開題，關於

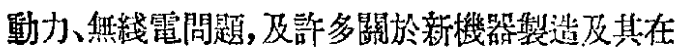
生崖上的技術學的原理，生堂程宗的自動伦和遠 距㒛控制化, 計算機的技術學, 彈性理論, 可塑性 理論，及其他關題。可惜地，同1951年計亚一樣，許 多重要的問題淹浔在大量數目的次等問題中，結

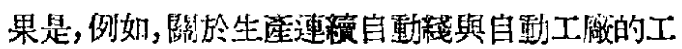
作，以及繁重操作程序的機俄化的工作，因而浑 有計劃到充分的程度，雖然科學院主席嘈會屨次 指明對於此類的工作有冭分摭展的必要性。關於 這樣的一些技術學問題, 如水力工程、運輸、熱力 發動機等也也沒有計割到充分的程度，本部叶标幾 倜機椿沼有以應有的注意力加到關於偉大共產主 義建設的工作上。關於這一點本部應當探取强有 力的措旅。

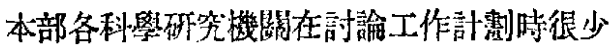
邀請政府各部各部門研究所和各企業部門的代表 參加，這對本部的整凮計割產生了很壞的影響。 本部應當重新研究自己的計劃，以保登對於

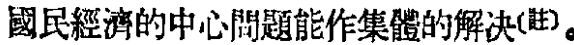

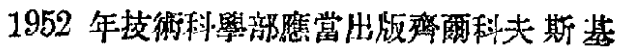

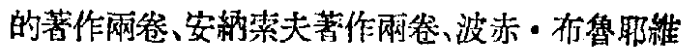
奇著作一勨及院士葛列師金等的著作。

\section{六 交翼興語言部}

以院士 B.B.䋖諾格勒多夫篇首的語言學研究 所在 1951 年工作的很紫㖘，其目的在筫現斯人株 在“熙克思主䔐與語言學問題”天才著作中對於蘇 稚埃語言學者所提出的重大任務。研究所已經绶 表泣準備付印關於普通語言學，和俄羅斯語言與

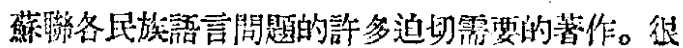
接近地解决了與各分院和各加盟共和或科學院科 學機關在活㣫上配合的問題。黨斯大林諭語言學 著作發表一週年紀念陑召開的六月會議中程極渗 加工作和討諭的有格魯吉亞、点克蘭及其他加盟 共和國的部言學家，在語言學的工作中现有的一

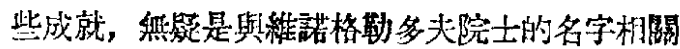
联的。

所有一切已作的，只能視第賽現折大林所提 出的任務的開始。吸收院外語言學家寥加廣诘的 創造证詮討諭還未得到礁有的發展, 由斯大林語言

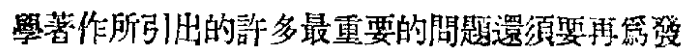

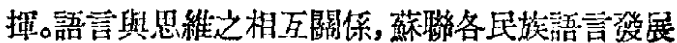

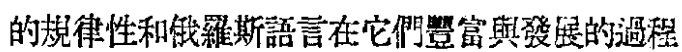
中所起作用，語言發展之內部規律，民族語言與部 族語言之區分，作筑俄䌖斯民族語言之基磷的，庫 爾斯克、奥勤爾方言，愁史比較法，語族的來源，名 詞學,字形學,字典與敉課書之編蝶——在1952年 計劃中，研究以上一切的問題使蘇維埃語言學在 世界語言學中仙第一偑位造。

如问 1951 年一樣，也将要會同分院研究所和 各州盟共和或科學院研究所舉行聯合討諭會, 計 劃組織公倜考察隊研究俄囉斯的方言，以及最少 被研究的我們北方和高加素的語言。

計劃於 1952 年初即出版全蕉的通俗科學竦 誌“語言學問題”。這侸程誌對於統一語言學者的 力量, 和語言學的科㶅工作之配合上將有重要的

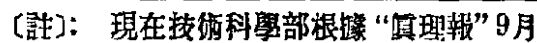

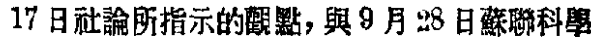

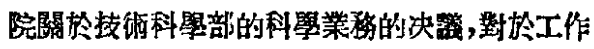

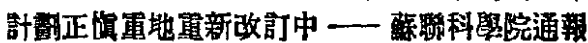
㭾者按。 
意義。

須要注意的是，遣很有一些馬爾的“鹤門徒”

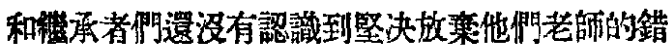
語觀點，立且改造他們自己的思想的必要性。如院

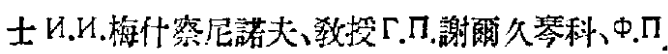
斐林、J.И. 日爾克夫、M.M. 古赫門、A.B. 德斯婮茲

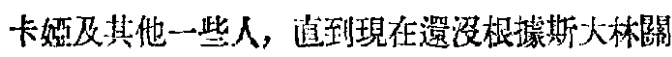

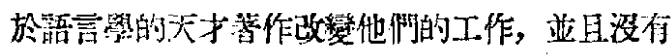

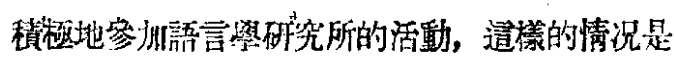
不能聑容忍下去的。

1952 年文學部門的各研究所將要絓訂關於

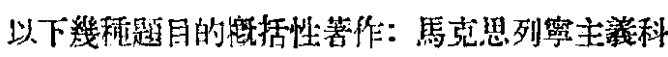

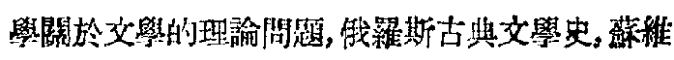

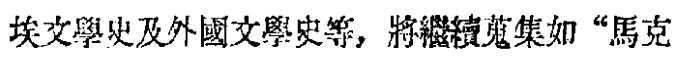
思、恩格斯與文學”, “列宜與斯大林諭文學”，“文 學理諭的基本問題”, “語言與文學” 等理論性諭 交集。

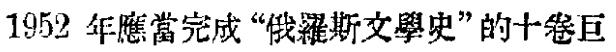

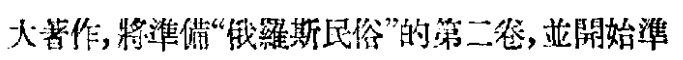

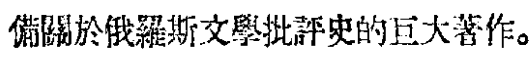

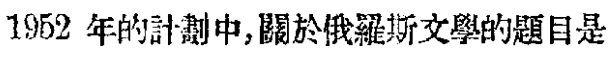

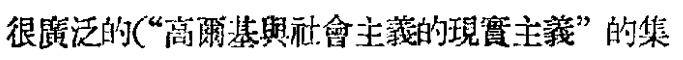
铻著作)。将要完成討論戰後階段文學的“做羅斯

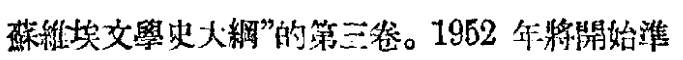

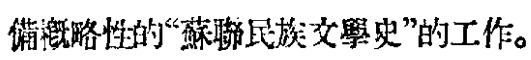

在研究外國文學方面, 將程續琵於法國的、英

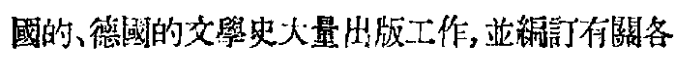
人民在主國家文學連動的論文集。

问過去隻年一榡，科學院的各交學研究所將

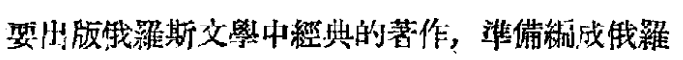

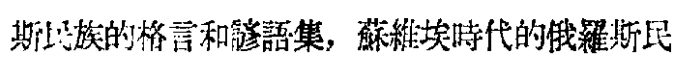
間創作牶。

杖年五月問科學院的各文學研究所舉行根據

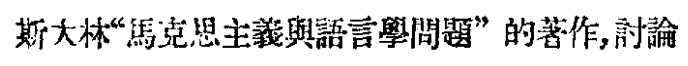
文學閏題的聯合會議時, 使深到的理論工作有了 開端，泣推動了關於文藝評價問題的廣泛而有創 造性的䛎馀底開展。

儖管如此，我們文學界的中心在解决俄羅斯 文學和文學批訐的基本問题上，顯然仍有不够的 地方,特别是俄释斯文學研觉所(普希金故居)的 業務。直到現在科學院的文學研究機楧同蘇維埃 作家坫會在業務上還汥有取得密切聯系。
不久以前，科學院主席國會指出俄维斯文學 研究所對出版經典作品的工作遭不能令人湖意， 特別是關於出版伯标斯基和果戈里的作品。在饬 偖“俄羅斯文學史”䐓次出版卷本的工作上，也是 照鹤不叮容忍地落後於期限。

如果我們的票䨩學家和交學家在斯大林的天 才指示的鼓舞下,能展開應有的批評和自我批棓,

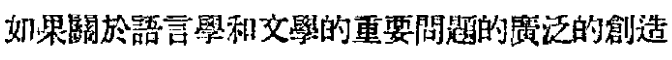

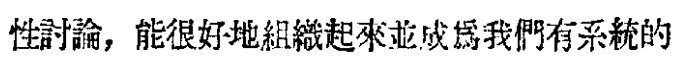

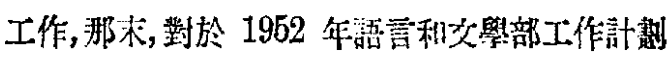

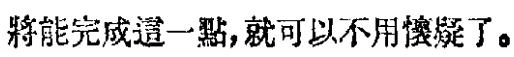

\section{七 歴史與哲舅部}

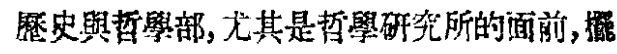

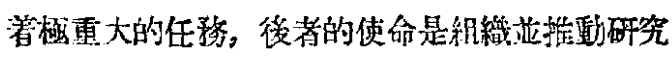
默克思列密學說中的漫電要問題。

斯大林同志的著作“正克思主義與語言學問 題”, 除了解决了語言學的問題外，對於犝證唯物 諭與歴史唯物諭中最重要的問題又侍天才的發 挥，它引起了我國晢學家、歷史學家、考古學家、人 稞學家、熱術學家底科學創造䅡極性的住力的高 碾。

二卷集“哲學史”樣本的縓成，關於諘證准物 諭的各種專諭的出版, 住在斯大林關於語言學著 作指導下討論哲學問題的大量報告的科學會䛾的 舉行一一這一切表明哲學研究所的工作已開始轉 變,轉變到解决我們現洔迫切任垎方面。

1951年本部門别的研究所的工作效率也此較 大的是:歷史研究所, 東方學研究所, 斯拉头學研 栄所, 人種學研究所和物質文化次研究所。

但是，本部中有幾個研究所的業務還是有些 嚴重缺點, 現在必須力求克服, 以求在 1952 年能保 篮工作按計毁進行。

由於斯大林關於語言學問題的天寸著作所伸 引出來的問題，如基礎與上层廷策的相互作用，在 社會現缘體系中科學䁷術和交學的地位, 語官與 意識的相互關係，文法與運輯的相互關係等等，篇 解决這些問題所需的一切, 都還浔有完全淮储好。

在人種學研究所和物質文化史研究所的業務

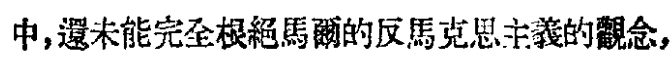
東方學研究所在研究東方語言學的領域中還未能 强有力地發揮理論工作。斯拉夫學呼究所沒有能 
够充分地結合必要的幹部從事研究東部斯拉夫語 㝘問題。

本部各研究所於 1951 年所計劃的 220 項工 作，在上牛年已經蘭造了 35 项，其中有幾項大 有終止的危险。藝術史研究所就有 11 種工作在 1950年就以雼結束了，但是，後來不是因絾發覺還 不適於运編輯出版會議，就是被會議和緛輯部退 還了。

東方學研究所中還有某些屬於馬爾底“阴徒”

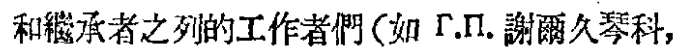
B.K.巴失克夫，H.C.柏拉金斯基，K.M.㰧沙尼等教 投)，直到現在還未用自我批垀分析他們以前馬爾 思想的萻作。但是，研究所領導方面給他們機會裝

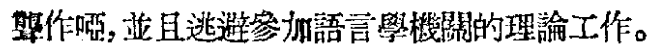

1952 年本部科學研究工作計劃的主要內容 是現代的首要問題一一蘇聯共產主義社會的建 設, 和共滻主浽宇宙顴的形成，與帝国主義陣營 中現代思想家的反動觀點玨争，揭發凟產階級的

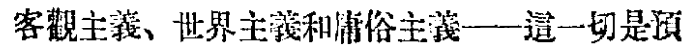
定在計劃中的掌前任勃。

計亚中分篇四組問題:

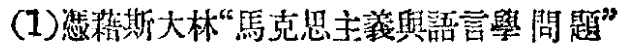
的天才著作，弡展点克思列寧主義的理論;

(2)蘇聯交的問題;

(3)通史的問題；

會

（4）斯拉夫各民族與東方各民族的文化 與語 言。

計劃中特别拄意研究以下的問題：斯大杪發

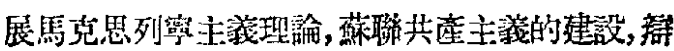

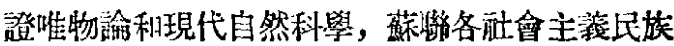
的形成。

同時也將研究以下的問邀：蘇聯工人階級與 農民的歴史，蘇聯各民族反對外國侵略者的鬥等， 斯拉夫人民民主的歷史，東方民主國家的㷴史，經 濟和文化等等。

1952 年工作計劃中，準備集體的“稀聯歴 史”、“世界史”和“世界的民族”等巨大篇幅著作也 佔重要地位。

大部分的題目是用集體研究方法，是幾话研 究所的學者共同參加的。

在哲學範園中，特研究下列的題目：“斯大林 的著作中讋證唯物論的發展”, “斯大林論靕 會主
義社會的經㳔基礎和上庴建笑”，斯大林“馬克思 主議與語言學問題”著作中的“誴證唯物論與歷史 唯物論問题”, “諭社會主義逐漸過渡到共这主主義”, “共產主義偷理學的基礎”, “时社會主義逐潮過渡 到共產主㼁時期的社會主㼁科學”, “巴甫洛夫學 說一一反對生理學唯心論的阿争武器”等等。

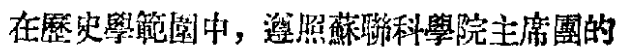
决議，計㳟中预定準借以下的概括性多突集著作： “蘇聯歷史” 16 卷, “世界史” 10 堭, “莫斯科史” 7 管, ”列玨格勤史” 4 怣, “俄羅斯陸軍與海軍史” 4 卷。斯拉夫學研究所將要付印“摭克斯拉夫史”, 同 時該所將繼儥“保加利亞交學史”的工作，並會同 語言學研究所準備“歷史比較法與斯拉夫語言學” 的論文集。

東方學研究所工作人員將進行組織“工人階 級在殖民地民族革命中爭取领導權的閏爭”、“中

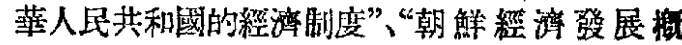
略”、“朝鲜新歴史大網”、“越南現代史 綱 要”、“澳 大利亞與太平洋集囸”等論文勧的工作。除此以 外，亚準储關於中國、日本、土耳其、印度、絔甸和 菲律賓的近代史和現代史，交學和語言的研究工 作。

篇了研究訃劃中規定的研究題目，預定了鼠 行26程考占學的和人程學的科學考察, 其中特有 最重要意義的是去共产主義偉大建設區域的科學 考察工作，即是占比雪夫和斯大林格勤水電站，以 及土庫曼大連河建築區的考察工作。

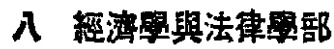

1952 年本部門科學咞究工作計乵包含 98 项 題目比䡆 1951 年的 160 項減少了許多, 題目數目 這樣急劇減少，表明集中力量研究我國經淙、國家 建設和法律中主要問題的必要性。

1952 年將㴗繼續研究证會主㼁經摔體 系和 萑維埃國家制度的規律性與優越性，蓝且霞進一

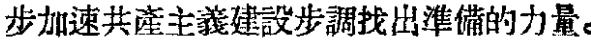

1952 年計劃中很大一部分問題是分析現代

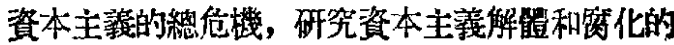
因素，揭露以美國篇首的帝國主義陣營的侵略政 策，在经濟學和法律學範国內批制資產階級的反

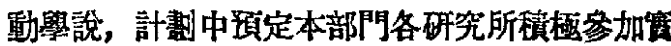
現偉大共産主義建設的工作。 
程㵂研究所按照考察研究計劃獀定組織互倜

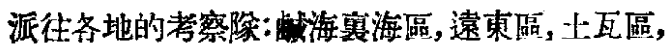

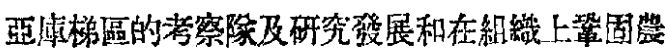
業營動組合問題的特别考察榢。

1952 年計㗲的特點是以聯合和集體次作方 法研究探定的題目，例如1951年計劃计的題目“工 羓企業的生產成本”, “在施會主義企業中熟䍃勞 動力的演大輌生產”和部多其他題目，在 1952 年的 計劃中則合併列入“社會主義工業企業的經濟”扂 一集顝著作中，作分章與分部。

以前本部的兩倜研究所一一經济學研究所與

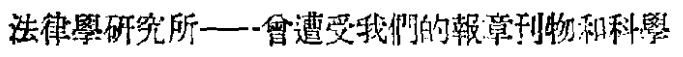

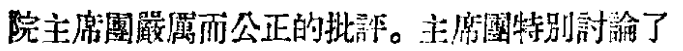
法膲學研究所的閣題，指出該所工作中准踶重的 錯留足與缺點。

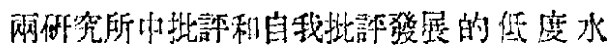

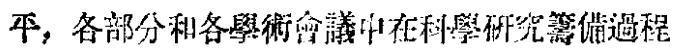

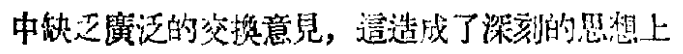
的錯留, 造成了传給出版界的科學作品質量的低 劣。

經濟研究所和法律研究所遗涩有谣了加强工

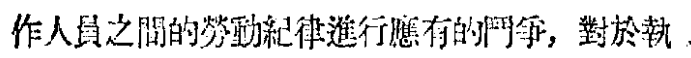

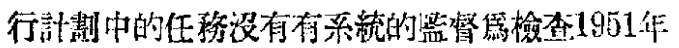

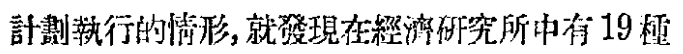
工作, 在法律學研究所有 6 種工作都有終止赫行 的危險。

經沾研究所和法律學研究所必需为强它們的 科學業務同蕉腹科學院各分院中各相當的研究所 和分部的活動間的配合, 蓝且和先潐的企業、工

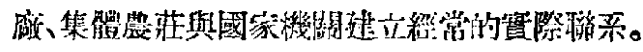

本部各研究所只付在對於以上列䀢的缺點作 堅决的听争的條件下，才能游底克服這種死氣沉 沉的情况。

\section{九 生産力研究委員雷}

1951年体會的工作計劃就预定進行研究蘇聯

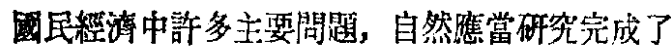
閶於所研究區域國民經游發最的一般性問邀，蓝

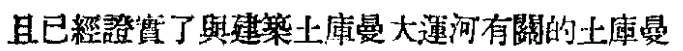

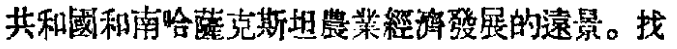
出了阿塞拜䎸共和國適於崖茶的區域等等。

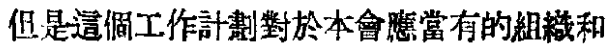

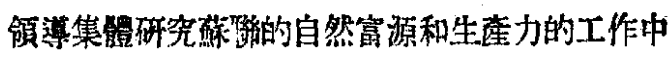
的領導作用，還浔有反蜰特别知得不够流分的， 是會同蘇㽧科學院地質研究所共同進行的研究工。

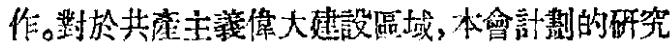
工作也是不够。

1952 年本會的工作計劃草菜中的開題和題 目反胦着黨和政府對於蘇聯科學院各機關所提:!

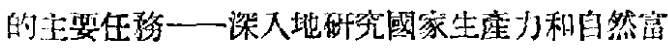
源。

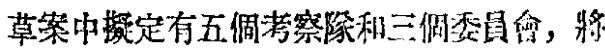

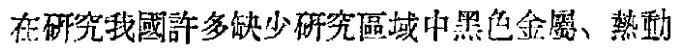

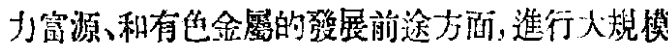

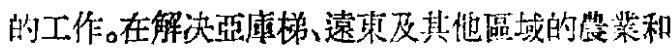
林業開題上，也釉進行大量的工作。

此外，本會特慗着手進行的:對於如们利活我 國束方、東萠方及其他區域中竍多貴重磷物的問

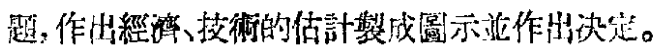

1952 年本會特特別注意: 研究土庫曼大運河

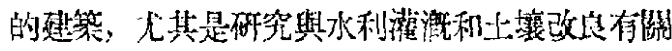
的阿姆河下游和土麻曼東部的地畨土壤，亚荘斷

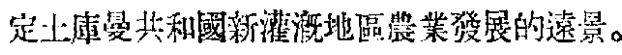

草䋈中的肯定方面是颔目的數目娍少:1951 年有 1966 项，1952 年減第 138 項。過渡超月世急 劇隇少: 過渡到 1951 年計劃中的有 134 项, 而過 渡到 1952 年的别減篇 106 項。

踓然本會的 1952 年工作补劃草案比上年䡴 䉆具體，較䍃滴合目的，但是它還是有着很多缺 點。首先，本會所計劃的與鮛聯科學院各研呪所 各分院以及各共和國科學院會合進行的集體 $-E$ 作 還是不够充分。

\section{+ 分院墖議}

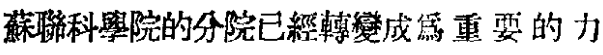
量, 它們與科學院的中央機關共同進行着入規模 的科學研究工作，參加解决國民經濟中的最重要 問題。分院研究各共和國、各傻區、各尛的天然富 源, 尋求出許多工業和農業部門提高生産量的方

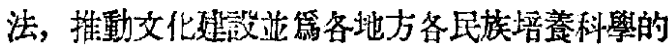
幹部。

在各分院的工作中有了很重要的改進，由於 完成 1951 年科學研究計劃的結果, 科學院各分 院供給工業和農業中應用的研究結果就超過 250 
種。

在國家㤫用計劃草案中, 有 $\$ 0 \%$ 的工作是蘇 聯科學院分院完成的。

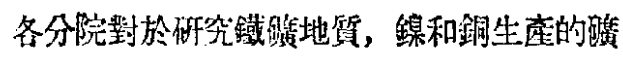
物原料，做了很大工作。有幾偑分院與科學院的各 中央研究所共同對於石油和煤氣的地質研究也做 了許多重要工作。

但是，分院的業務也有些嚴重的缺點，分院內 部各部分和各研究所間，以及分院與其他科・學硼 究機關間的工作聯系仍然不够，這是缺點之一。分

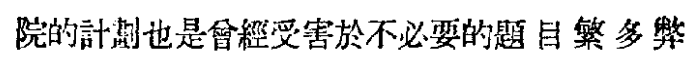
病。

還有一储缺點不能不說的, 就是蘇聯科學院 各部門和各中央科學研究機開對於分院的科學工 作的領䆃不够。

1952 年初蘇聯科學院共有十五處分院 和一 個研究站，其中一處——巴什基里亞分院一一是 才成立的。

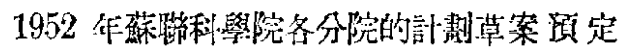

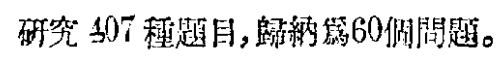

1952 年的計灃草案與 1951年的不同處, 是其 中擬定呼究的有很大一部分是有關整個國家的問

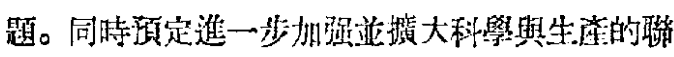

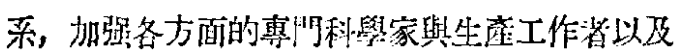
各部鬥研究機關的工作人員的聯系。例如，將由分 院各砄筦機關間自己配合埶行的工作有 48 项，同 各部阿研究所和工激研究室配合的有70 项, 同蘇 聯科學院各中央機構配合的有 28 項。

在㟆借各分院 1952 年科學研究計劃時, 各分 院管與地方企業和政府各部取得密切聯系, 計㐜 是完企得到各共和國國家計割局、和蘇維埃與黨 組織的領導上的司意的，亚且是經蕉聯科學院各 部也討論過的。

蘇聯科學院各分院在它的 1952 年工作計劃

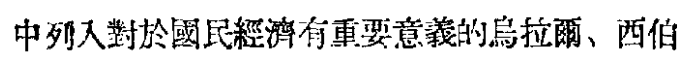

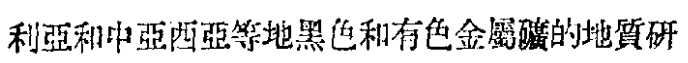
究。

研究新石油區域的石油和㖼氣的地筧學工作 在分院的計劃中佔重要地位。這些工作將管會同 蘇眑科學院石油研究所共同進行的。

除了旨在援大治金工業上必需的原料的出產 基地的工作外，有很多分院按計劃還發展以下的
工作：以物理化學方法研究磺地以求獲得自複燓

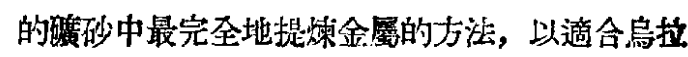
爾、吉濔吉斯和遠東各最重要的工業目標; 研究金 屬物理學，以求得到硕定性質的金屬; 研究冶金工 業與機器製造工業中，檢查成品質量的器具和材 料。

1952 年按照其計劃各分院彩要進行有關共

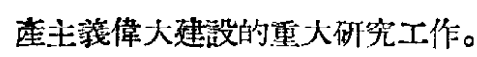

計劃中規定了在農業生物學範園內相賞大規 模的研究, 主要的目的是研焭人工灌溉區域中農 業技術的科學基碟。

又計劃研究防護林的唔植，研究集中砍伐下 的森林復生法。

斯大林關於語言學問題的天攵著作，對於各 分院在研究許多加盟共和國和自治共和國各民㐨 的語言、文學和歷史問題上的研究方針和題目的

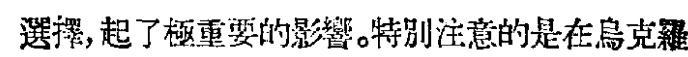
蘇蘭的、严庫梯的和科米的語言中, 研究其合乎科 學的交法。各分院不斷地提高研究題目計劃的質 量, 改善其執行的結果。

但是，個别分院的工作計劃仍然有不少㩔重 的缺點。

吉爾吉斯分院和遠東分院仍然是受題目太多 之害, 工作完成期限也往往延長, 研究的結果有時 不能具體化，有絏储分院對於自己間以及與各部 科學機棈, 特别的是與蘇聯科學院各中央研究所 間的配合汥有計劃好。

各分院、分院會議和科學院各部的基本任務 中的一項是對於 1952 年語劃草案頂定的一些最 重要問題要更加强其集體的研究方法。

科學院所有各機關嫄賞特別注意及時完成與 偉大斯大林共産主戔建設有關的工作。

必須䍃縮短工作結束時間，篇減少有過渡性 題目的數目而進行堅决的閏学。

必须減少 1951 年過渡來的題目數目, 不只要 争取完成本年的計劃䢩要爭取超額完成的任務。

我們可以相信的，我們的學者紹對不會莘負 黨和政咐的信任，他們將保镫你决共產主義建設 所提出的科學問題，綡不負我們的人民，我們的黨 和斯大林本人對於科學的重大鼠㜊。

[何思源譯自“程聯科學院通報”1951年第10期]

第六期科學通報 